\title{
DIE ONTSTAAN EN DIE ONTWIKKELING VAN DIE SKOOLKADETTE-STELSEL IN DIE RSA: GREPE UIT DIE GESKIEDENIS EN 'N OORSIG OOR DIE HUIDIGE STELSEL
}

Kol M.J. Viljoen*

The origin and development of the school cadet system in the Republic of South Africa is dealt with in this article. A historical revue is furnished as well as a perspective of the present system.

\section{Historiese agtergrond}

Alhoewel die ontstaan van die eerste sogenaamde kadetkorps tot die tweede helfte van die negentiende eeu teruggevoer kan word, het Simon van der Stel reeds by wyse van 'n kennisgewing 'n militêre verpligting op alle seuns bo die ouderdom van nege jaar geplaas. Hulle moes naamlik voorbereidende opleiding ontvang in dril en skietkuns sodat hulle op sestien jarige leeftyd by die Burgher Militia (wat op 2 Julie 1687 gestig is) vir diens moes aansluit. Die kennisgewing wat op 22 Desember 1687 uitgestuur is, het onder andere gelui:

"Verders is beslooten en ten meesten dienste deser Colonie eenparig goedgevonden de kinderen deser ingesetenen, te weeten de knegtjes van negen tot derthien jaren ouderdoms, alle Saturdagen's namiddag op de drilplaats in de wapenhandeling door den drilmeester te doen oeffenen, en deselve op 'n niewejaars dag onder haar vaandel te doen optrekken, op arbitrale boete by haar respective ouders te verbeuren, ingeval iemand sonder wigtige reden in gebreke blijvt daar te verschijnen."

Die bestaan van die "Jongen Brigade" in die geboortejare van die Kaapse geskiedenis was egter nie die voorloper tot die huidige kadetstelsel nie. Ons kadetstelsel waarvan die eerste "korpse" in Natal en die Oos-Kaap gestig is, is 'n afstammeling van die kadetorganisasie wat in Engeland in 1860 ontstaan het. Dit is ' $n$ interessante stukkie geskiedenis wat soos volg lui:

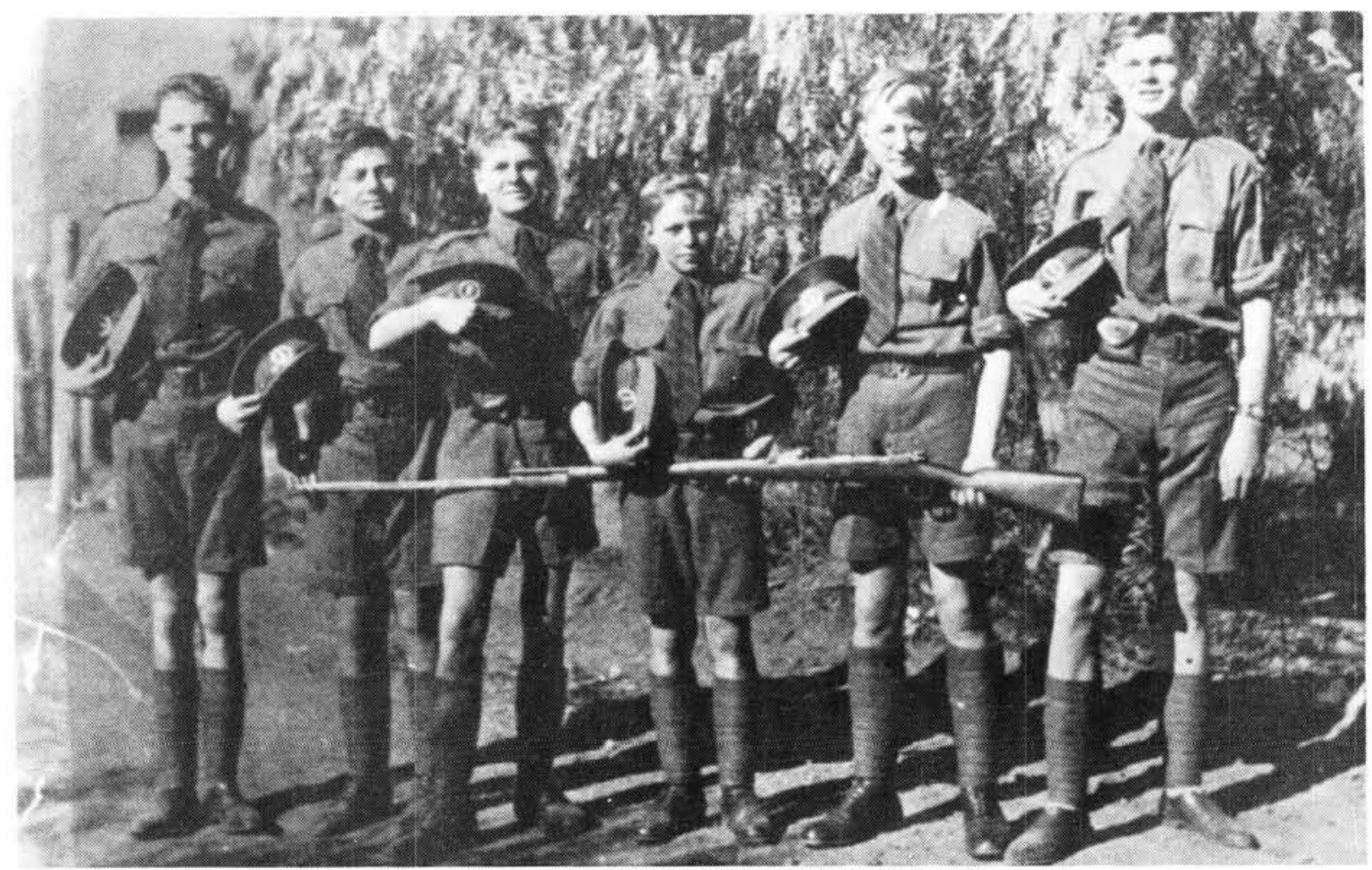

Skoolkadette van vroeër jare, uitgevat in hulle kadetuniforms 
Vroeg in 1860 het 'n lid van die Queen's Westminister Rifle Volunteers, ten spyte van proteste van ander lede van die Regiment, sy twee seuns in die regiment se uniforms geklee en hulle in die eenheidslyne laat paradeer. Toe die bevelvoerder, die Graaf van Grovenor, dit sien, was hy baie ingenome daarmee en het voorgestel dat meer seuns gewerf moes word om as lede van die Regiment te paradeer.

In Mei 1860 het ongeveer ' $n$ peloton kadette (so is hulle genoem) die Regiment se revue-parade, ter ere van die Koningin, Hyde Park binnegelei. Die deelname van seuns aan die Regiment se vertoonoptrede het ' $n$ instelling geword en hierdie kadette het sedertdien die voedingsbron vir die Regiment geword. Seuns tussen nege en sestien jaar het in die kadetkorps gedien waarna hulle volwaardige lede van die Regiment geword het.

Dit word beweer dat die eerste skoolhoof van Hilton College (Natal), Reverend William Orde Newnham, bogemelde parade bygewoon het en dat hy daarna die "Hilton Guard" in 1872 gestig het. Die "Hilton Guard" staan vandag bekend as Hilton College Kadetafdeling No 1.

\section{Die eerste kadetafdelings in Natal}

Hermannsburgse Kadette. Daar is aanduidings dat kadetkorpse reeds voor 1872 in Natal gestig was. In 1853 het 'n Duitse sendeling, pastoor Johannes Heinrich Muller hom by Hermannsburg (in die huidige Greytowndistrik) gevestig. Uit hierdie sendingstasie het die Hermannsburg Duitse Skool gegroei met pastoor Muller as die hoof van 1862 tot 1871 . Hierdie skool wat Duitse- Hollandse- en Engelsprekende leerlinge gelok het, was ook die eerste kosskool in Natal. Genl Louis Botha, die eerste Premier van die Unie van Suid-Afrika, was onder andere 'n leerling van die skool. In 1869 (sommige bronne sê 1868 ) is ' $n$ kadetkorps by hierdie skool gestig. Die waarnemende Goewerneur het 'n klein finansiële toekenning aan die skool gemaak, en die kadetkorps laat uitreik met Terrykarabyne, ammunisie, skywe en 'n Union Jack-vlag. Die 40 seuns, tussen die ouderdomme 14 en 18 jaar, was afgerig deur ' $n$ ex-onderoffisier van die Hanoverse Leër in dril en skietkuns. Geen uniforms was beskikbaar nie. Die groot seuns het met die karabyne marsjeer, terwyl die kleiner seuns besem- en wandelstokke gebruik het.

Hierdie kadetkorps het vrywillige diens gedoen tydens die Langalibalele Rebellie en het voortbestaan tot 1878 toe dit ontbind is.

Durban High School. In 1866 was Durban High School geopen met Mnr Robert Russell as die hoof. In dieselfde jaar het die skoolseuns tweemaal per week drilonderrig ontvang. In 1868 is die Durban High School bataljon amptelik gestig en was hulle uitgereik met karabyne en ammunisie. ' $n$ Eiesoortige uniform was deur die ouers vir die seuns gemaak. Op die Koningin se verjaarsdag in 1871 het 'n kompanie van 80 kadette vir die eerste keer in Natal saam met permanente en vrywillige regimente aan 'n parade deelgeneem.

\section{Hilton College en Martizburg High School. In} Oktober 1873 het daar reeds vier kadetkorpse in Natal bestaan, te wete Hilton College, Maritzburg High School (Vandag Maritzburg Collegekadetafdeling no 2) Hermannsburg en Durban High School (kadetafdeling no 9). Die Hilton Guard wat in April 1872 gestig was, het bestaan uit 40 seuns op perde. Hulle was die eerste berede kadetafdeling in die Britse Ryk. Die "Guard" het saam met ' $n$ troep ('n gedeelte) van die Natal Carbineers opleiding gedoen en in Oktober 1873 het eersgenoemde die jaarlikse skietkompetisie teen die Carbineers met 24 punte gewen. Die telling was 145 punte teenoor 121 punte. Die Hilton Guards het aan die Langalibalele Opstand in 1873 en aan die Zulu-oorlog in 1879 deelgeneem. In dieselfde jaar het hulle weens ' $n$ tekort aan perdevoer oorgeskakel na 'n infanterie-kadetafdeling.

\section{Die eerste kadetafdelings in Oos-Kaap}

Verskeie kadetkorpse is ook gedurende die sewentiger jare van die negentiende eeu in die Oos-Kaap gestig.

\section{Panmure Publieke Skool.}

In 1876 het Pastoor Muller (vroeëre hoof van Hermannsburg Skool) hoofskap aanvaar van die Panmure Publieke Skool in Oos-London. Alle seuns bo 15 jaar is ingeskryf as lede van die plaaslike mag om die dorp teen die opperhoof Gaika tydens die Negende Grensoorlog te beskerm.

Die kadette was uitgereik met ' $n$ paar Snidergewere en moes twee blokhuise by die noordelike ingang van die dorp bewaak. Die visehoof van die skool, Mnr Armstrong en van die senior seuns het ' $n$ aktiewe aandeel gehad om ' $n$ aan- 
val van die Xhosas af te weer. Panmure Publieke Skool kadetkorps is in 1896 verander na die Oos-London kadetkorps en in 1909 het die Selborn College kadetkorps geword.

St Andrew's College. Die kadetafdeling van St Andrew's College was in Oktober 1877 gevorm om 'n moontlike aanval van die Xhosas teen Grahamstad af te weer. Die seuns was met voorlaaiers uitgereik wat in 1879 met Sniders en bajonette vervang is. St. Andrew's College se kadetafdeling is vandag Kadetafdeling no 4.

Queen's College. Die Queen's High School (nou Queen's College, Kadetafdeling no 3) was die eerste kadetafdeling om in die Kaapkolonie amptelik erkenning te kry. Dit is ook in 1877 gestig en het in dieselfde jaar die regering se erkenning gekry as ' $n$ deel van die Vrywillige Mag toe die kadette in Desember ingesweer is as lede van Haar Majesteit se Magte. Hulle is in 1879 uitgereik met Snidergewere, bayonette, lyfbande en ammunisietasse. Laasgenoemde twee items moes spesiaal in kleiner nommers bestel word.

Die stigting van die kadetkorpse in Natal en die Oos-Kaap was dus ' $n$ direkte gevolg van die dreigende asook die werklike botsings met die inboorlingvolke. Maw kadetkorpse was gestig om huis- en haard te beskerm. Die doel van die kadetkorpse in die vorige eeu is duidelik gestel deur die Minister van Landbou, Mnr Johnstone, toe hy die kadetafdeling van die Ixopo Goewermentskool toegespreek het. Die Natal Witness van 8 Maart 1898 rapporteer so oor Mnr Johnstone se toespraak:

He said that there was no doubt the boys would some day have to fight for their homes and they could do no better than learn how to do that. "We are living amongst an enormous black population, and every white man in this country should be efficient in drill and the use of arms, because they did not know when they might be called upon to use them on account of the enormous hordes of natives by whom they were surrounded."

Gedurende die laaste dekade en 'n half van die negentiende eeu is kadetkorpse in feitlik al die sekondêre skole van Natal en die Kaap-Kolonie gestig.

Tydens die Eerste en die Tweede Vryheidsoorlog het sekere kadetafdelings en individuele kadette ook aktief by die oorloë betrokke geraak.
Van die Hilton College se kadette, byvoorbeeld wat in die Transvaal woonagtig was, is in 1896 tydens die Jameson-inval opgeroep. Toe Genl Joubert se kommando's Natal binnegeval het, het drie van Hilton se seuns vir diens aangemeld en met die Britse Magte gedien tot na die ontsetting van Ladysmith. Cyril Francis "Ginger" Bain en Jack Donaldson was toegelaat om die oorlogslinte te dra tydens parades van die Hilton-kadette. 'n Ander voorval waarby kadette 'n aktiewe rol gespeel het, was toe Genl Smuts se magte op Sondag 10 Maart 1901 by die Amatolaberge deurgebreek het en op Grahamstad aangemars het. Behalwe vir ' $n$ klein afdeling van die Berkshire Regiment, die plaaslike Town Guard en 96 St Andrew's College kadette (bo 16 jaar) was die pad oop vir die aanmarsende magte van Genl Smuts. Die seuns bo 16 jaar was elk met 'n Martini Henri-geweer, 50 rondtes ammunisie en 'n khaki-uniform uitgereik. Die jonger seuns se taak was om die magasyn met reserwevoorrade te beskerm. Gelukkig het die Kommandos van rigting verander en Grahamstad verbygesteek. $\mathrm{Na} 10$ dae se gereedstaan is die situasie van die dorp veilig verklaar. ' $n$ Week later het elke seun, wat diens gedoen het, 'n koevert ontvang met 10 dae se soldy vir 'n manskap of onderoffisier teen heersende soldyskale. Die seuns het eenparig besluit om die geld te gee as ' $n$ bydrae tot die skoolsaal wat in aanbou was.

\section{Die stigting van kadetkorpse in ander skole}

Ander kadetkorpse wat gedurende die laaste dekade van die negentiende eeu gestig was, is Muir College in Uitenhage, Michaelhouse in Balgowan (Natal) Graeme College (Grahamstad) Wynberg (Kaapstad) en St Aidan's College wat later ontbind het.

Reeds in Oktober 1894 was daar aansoek gedoen vir finansiële ondersteuning om ' $n$ kadetkorps by die Muir Academy te stig en op 2 November 1896 het die korps effektief geraak met ongeveer 50 seuns. Die hoofaktiwiteite was dril, skietkuns en orkeswerk. Soos die geval was met ander kadetafdelings is hierdie kadetkorps se gewere (Martini-Henrys) met die uitbreek van die Eerste Wêreld Oorlog gekommandeer om dit onder andere ook teen die Rebellie in 1914 te gebruik.

Die kadetkorps van Michaelhouse is ook in 1896 gestig. In 1904 het hierdie Afdeling hom onderskei deur eerste te kom in 'n skietkompetisie 
waaraan die 14 topkadetafdelings van Natal deelgeneem het. Hulle moes egter tevrede wees met 'n 49ste plek uit 68 Afdelings wat aan die Britse Ryk (Empire) kompetisie deelgeneem het. Die verskoning was dat die Unie se kadetafdelings met Martini-Metford gewere moes kompeteer teen die Lee-Enfield gewere van die Britse kadetafdelings.

Die Graeme College kadetkorps is in 1879 gestig en is in die begin van 1880 deur die Goewerment met gewere uitgereik. Alhoewel hierdie kadetafdeling gou daarna 'n reputasie vir skietprestasies opgebou en baie privaat kompetisies gereël het, het dit eers in 1913 'n eie skietbaan gekry.

\section{Wynberg Boys' High School se kadetafdeling is} in 1899 gestig nadat die Trustees 'n wapenkamer kon bou en genoeg gewere kon bekom om die Afdeling uit te rus. Met die uitbreek van die Eerste Wêreldoorlog het baie van die seuns, sommige jonger as 15 jaar die wapen opgeneem. Oor die 400 kadette van hierdie kadetafdeling het diens gedoen in Haar Majesteit se Magte. Drie en veertig seuns het nie teruggekeer nie.

Dit is dus interessant om te weet dat agv die deelname en betrokkenheid van die eerste kadetafdelings in Natal en Oos-Kaapland by Grensbotsings en by die Eerste en Tweede Vryheidsoorlog asook die Eerste en Tweede Wêreld Oorlog hierdie kadetafdelings ' $n$ trotse militêre tradisie het. Hulle geskiedenis is nou verbind met Regimente met wie hulle sedert daardie jare geaffiliëer was en vir wie hulle as 'n voedingsbron gedien het en steeds dien. Sommige van hierdie kadetafdelings het dan ook herhaldiesgoedgekeurde vaandels.

Hulle hou jaarliks seremoniële parades om hulde te bring aan diegene van hulle Afdelings wat in veldslae gesneuwel het en om hulle trotse geskiedenis en tradisies te herdenk.

\section{Die eerste kadetafdelings in Transvaal}

In 1902 was daar 'n totaal van ongeveer 700 kadette en 17 offisiere in die Transvaal, genoem die Boy's Brigade. In dieselfde jaar is ook die Transvaal Volunteers gestig - soortgelyke organisasies as wat in die Kaapkolonie en Natal gestig was. Die eerste kadetkorpse het dan ook direk onder die hoofkwartier van die Transvaal Volunteers geval. Ongeveer 1904 was die vol- gende kadetafdelings gestig: Die Boy's Brigade, Jewish Lad's Brigade, Jeppetown High School kadetkorps en Marist Brothers School Kadetkorps.

In 1905 het kadetgetalle vinnig in Transvaal uitgebrei. Die kadetafdelings was in bataljonne georganiseer, onderverdeel in kompanies. Die eerste bataljon van ongeveer 750 seuns het hoofsaaklik uit skoolverlaters bestaan wat aan die Rand in kantore of as vakmanne werksaam was. Daar was kompanies in Johannesburg, Krugersdorp, Cleveland en aan die Oos-Rand. Die tweede bataljon, met ongeveer dieselfde sterkte, het net uit skoolseuns van verskillende kadetafdelings bestaan. Die derde bataljon van ongeveer 300 seuns het aan die Wes-Rand bestaan. Die vierde bataljon was gevorm uit seuns van Pretoria se kadetafdelings.

\section{Die Oranje Vrystaat}

Kadetafdelings of enige vrywillige elemente het eers na Uniewording in die Oranje-Vrystaat tot stand gekom.

\section{Die stand van die kadetstelsel in 1913}

Op 30 Junie 1913, 'n dag voordat die totale kadetorganisasie statutêr in die Unie Grondwet opgeneem is, was die kadetsterkte in Transvaal, Natal en die Kaapkolonie soos hieronder aangedui.

\begin{tabular}{|l|r|r|r|}
\hline Provinsie & $\begin{array}{r}\text { Offi- } \\
\text { siere }\end{array}$ & $\begin{array}{c}\text { Ka- } \\
\text { dette }\end{array}$ & Totaal \\
\hline Transvaal & 135 & 3173 & 3308 \\
Natal & 32 & 3858 & 3890 \\
Kaapkolonie & 177 & 3943 & 4120 \\
\hline Totaal & 344 & 10974 & 11318 \\
\hline
\end{tabular}

\section{Vroeëre wetgewing en opleiding}

Alhoewel baie kadetafdelings voor 1900 gestig was en amptelike erkenning gekry het, het die eerste wetgewing in die verband in Natal in 1903 verskyn toe Wet no 36 van 1903 tov die Militia spesifieke Artikels oor kadette ingesluit het. Art 74 het die stigting van 'n kadetkorps vir alle skole verpligtend gemaak.

"Every Government or aided school or college in the Colony shall have instituted therein Cadet Corps, or classes of instruction in military drill, 
exercises and musketry; and arms and accountrements necessary for the instruction of cadets over the age of 12 years shall be proved at the public exspense."

'n Ander Artikel het aan die Minister van Onderwys en Opvoeding die magte gegee om onderwystoekennings te weerhou van leerlinge wat nie die opleidingsklasse gereeld bygewoon het nie. Met Uniewording was die bestaan van 'n algemene kadetstelsel in die Unie Verdedigingswet Wet No 13 van 1912 opgeneem. Hierdie wetgewing het van krag geword vanaf 1 Julie 1913 en kadette het 'n statutêre aktiwiteit binne in die Verdedigingswet geword. Art 6 van die Wet lui:

"In urban or other populous areas wherein facilities for the proper training of cadets can conveniently be arranged, all boys between their thirteenth and seventeenth years (both included) may be required to undergo a prescribed course of cadet training annually, unless their parents or guardians lodge written objection thereto."

Artikels 71 tot 75 het aspekte omskryf soos kadetopleiding, kadetoffisiere, wapens, uitrusting, uniforms en vrystelling van kadetopleiding.

In 1913 het daar ook ' $n$ handboek vir kadetopleiding verskyn. Dit gee die doel van kadetopleiding soos volg:

"It is intended that the training of Cadets shall be carried out in such a way that when the time arrives for them to join either the Permanent or Active Citizen Force of the Country, they will have been properly instructed in a variety of military subjects."

Geen formele of spesifieke vakke was egter voorgeskryf nie. Behalwe skietopleiding, dril en orkeswerk was ander opleiding aan die keuse en verbeelding van instrukteurs oorgelaat. Op 31 Augustus 1923 word daar egter in die Goewerment Gazette 'n amptelike leerplan voorgeskryf vir Graad 1 en vir Graad 2 kadette onderskeidelik. Alle seuns begin as Graad 1 kadette en moet die voorgeskrewe vakke slaag om 'n Graad 2 kadet te word. Die voorgeskrewe vakke vir Graad 1 was dril, skietkuns en orkeswerk. Opsionele vakke was semaforiese seine, Morse kode, knope en lasse, militêre higiëne, verkenning, kaartlees, swem en militêre woordeskat. Vir Graad 2 kadette was skietkuns uitgebrei om groter kaliber wapens in te sluit, terwyl milifere higiëne ook verpligtend was.
In die Goewerment Gazette van 4 Mei 1934 word die verantwoordelikheid vir die opstel van leerplanne vir kadette asook vir die inhou van kursusse aan die Direkteur van Militêre Operasies en Opleiding opgedra. Volgens hierdie Gazette was elke seun verplig om 30 uur per jaar opleiding te doen.

Met die groei van die onderwys en die stigting van sekondêre skole in die land het die getal kadetafdelings toegeneem. Onderwys en Weermag het kadette egter op ' $n$ redelik onbeplande wyse en sonder duidelike doelwitte bedryf. Op Leerhoofkwartier en Direkteure van Onderwysvlak was daar byvoorbeeld nie 'n formele skakelformule nie.

Aangesien daar geen geskrewe ooreenkoms tussen die Weermag en Onderwys bestaan het nie en kadette as 'n jeugaktiwiteit in die Verdedigingswet ingeskryf is, word die indruk gelaat dat kadette as 'n Weermagverantwoordelikheid gesien - ook deur die Onderwysowerhede.

Onderwysers het hulle beskikbaar gestel vir opleiding. 'n Korps vir kadetoffisiere het afsonderlik bestaan (die sogenaamde OKKO'S). Die Weermag (Leërkommandemente) het kompetisies in dril, skiet en orkeswerk gereël asook kampe en bivakke aangebied, en die kadetafdelings het daarby ingeval.

Sonder om in detail in te gaan (wat nie die bedoeling van hierdie artikel is nie) kan dit gesê word dat die kadetstelsel tussen Uniewording (1910) en 1976 nie groot veranderinge ondergaan het nie. Die twee Wêreldoorloë het beslis ' $n$ insinking in die stelsel ten gevolg gehad, veral weens 'n tekort aan onderwyseroffisiere en moontlik vanweë verdeelde politieke sienswyses. Wat die stelsel wel tot voordeel gestrek het, is die feit dat dit ' $n$ aktiwiteit binne die skoolprogram was en dit vir alle skole gerieflik was om daaraan deel te neem. Trofees vir die verskillende kompetisiefasette was deur die Britse Regering ingestel en die Uniekadette het daaraan deelgeneem, op hulle eie, maar as 'n lid van die Statebondsland. Die Uniekadette het egter tot ongeveer 1948 saam met ander Statebondslande meegeding om die Imperial Challenge Shield wat 'n soort posliga-skietkompetisie was en wat vanuit Engeland beheer was. Hierdie kompetisie is vervang met die huidige SA Tussenafdeling-skietkompetisie. (SATA)

Na Republiekwording in 1961 is die kompetisies hersien en is ' $n$ reeks nuwe trofees ingestel. 
Daar is egter nog enkele van die oorspronklik (egte sterlingsilwer) ingestelde trofees waarom kadetafdelings meeding. Die name van die trofees is egter verander en die reëls van die kompetisies het sekere wysigings ondergaan.

Tot ongeveer 1967 was kadette as deel van die kurrikulum erken en is opleiding in skooltyd gedoen. Die onderwysdepartemente was nie gelukkig nie aangesien die stelsel vir hulle 'n las geword het, veral tov mannekrag en tyd. Ewen- eens het die Weermag tot die oortuiging gekom dat die stelsel geen teenprestasie vir hom lewer nie.

Ironies is dat die bedryf van kadette afgeskaal is toe algemene diensplig ingestel is. Die diensplig het intussen sy volle beslag gekry en in Weermagkringe het die gedagte posgevat dat skoolkadette 'n deeglike ondersoek vereis ten einde die skoolgaande seun vir sy komende nasionale diensplig te oriënteer.

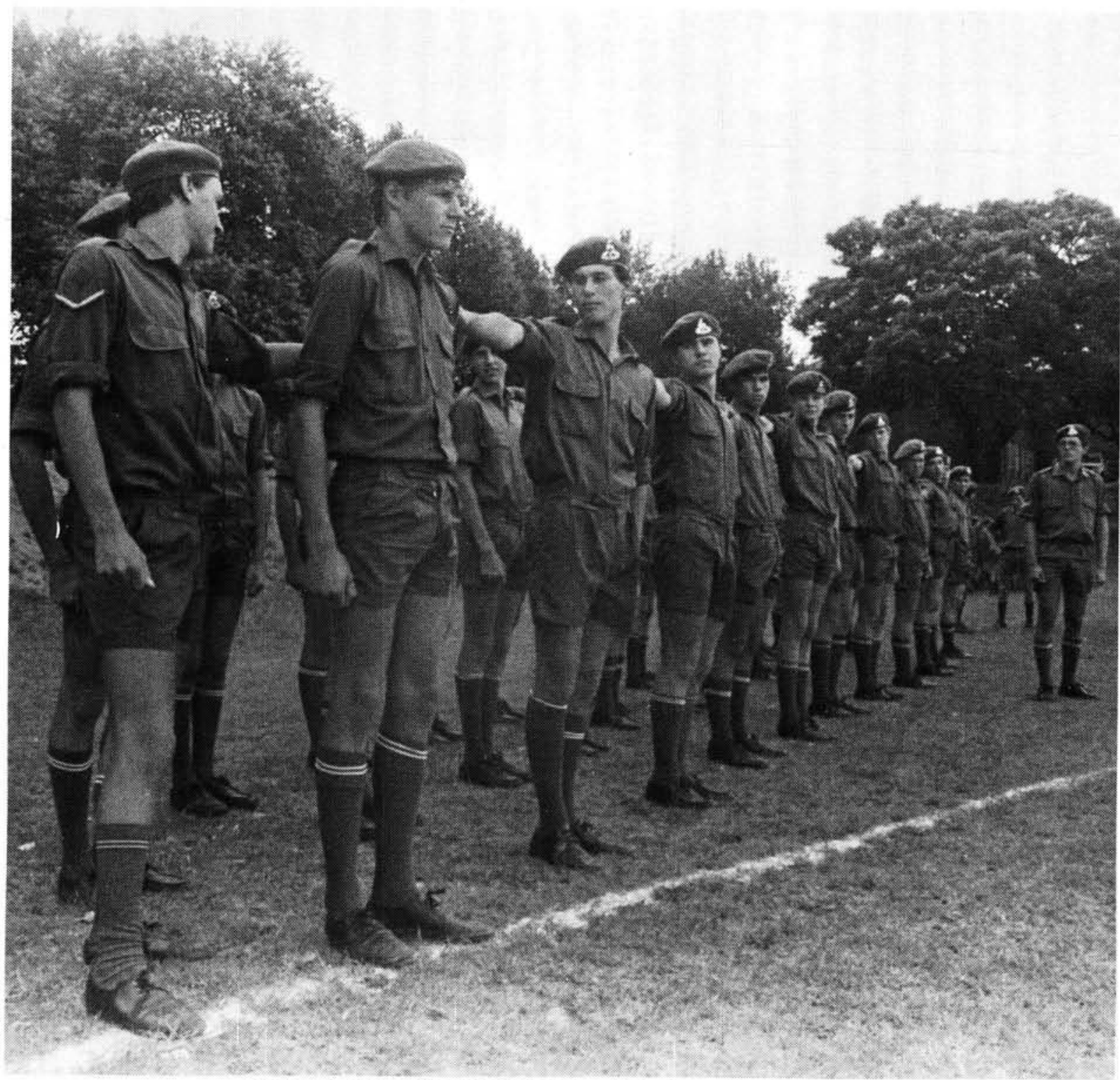

Tydens kadetopleiding leer die seuns al die tynere kunsies van dril 


\section{Die nuwe stelsel}

Samesprekings tussen die Minister van Verdediging en die Minister van Nasionale Opvoeding in 1974 het gelei tot ' $n$ opdrag aan die twee departemente om aan die hand van gegewe riglyne 'n gesamentlike ondersoek te loods en aanbevelings te maak tov: -

Behoorlike interdepartementele skakeling

'n Sinvolle kadetstelsel

Die implementering van die stelsel

Die komitee wat gevorm was om die ondersoek te loods, en waarna in die algemeen verwys word as die Loodskomitee vir Kadette, was saamgestel uit senior verteenwoordigers (adjunk-direkteursvlak) van al die onderwysdepartemente en verteenwoordigers van die Leër, onder voorsitterskap van die Departement van Nasionale Opvoeding.

Die aanbevelings van die komitee wat deur Verdediging en die Onderwys aanvaar was vorm die beginsels waarop die kadetorganisasie tans bedryf word. Hierdie aanbevelings is kortliks die volgende:

'n Interdepartementele komitee saamgestel uit Onderwys en Weermagverteenwoordigers sal toesien dat die stelsel behoorlik geïmplementeer word. ' $n$ Duidelik geformuleerde hoofdoelstelling asook sekondêre doelwitte is vir kadetopleiding gestel.

Alle seuns van St 6-10 in alle sekondêre skole in die land word by die stelsel betrek. Kadetopleiding kry sy eie tydstoekenning. Die skoolprogram moet sodanig georganiseer word dat ongeveer een uur per week aan kadette toegewys word op ' $n$ tyd wanneer almal daaraan kan deelneem. Hierdie kadetopleiding word aangevul met verdere na-uurse bedrywighede.

Spesifieke vakke word voorgeskryf vir junior kadette en spesifieke vakke vir die seniors. Die kompetisies moet sinvol wees en almal moet daarby betrokke wees. Kadette loop parallel met jeugweerbaarheid. Jeugweerbaarheid behou sy outonomie. Beide jeugweerbaarheid en kadette maak elk sy eiesoortige bydrae tot die weerbaarheidswording van die jeugdigde.

Die SA Weermag dra die totale begroting van die kadetstelsel. Alle SA Weermagopdragte moet via die Onderwyshoofde na die skole toe gaan. Alle onderwysers moet nasionale diens- plig doen en hulle opleiding moet andersoortig wees. Die voorgestelde kadetprogram is vanaf 1 Januarie 1976 geleidelik geïmplementeer.

Die Loodskomitee vir kadette het aangevoer dat die fondament van sukses vir die implementering van 'n deeglike, uniforme en betekenisvolle kadetprogram berus op deeglike interdepartementele skakeling tussen die Onderwysowerhede en die SA Weermag.

Die resultaat was die vorming van die Staande Interdepartementele kadetkomitee (SIK).

\section{Die SIK}

Die komitee is saamgestel uit ' $n$ senior verteenwoordiger van elke onderwysdepartement, en die senior stafoffisier kadette op Leërhoofkwartiervlak. Ander lede kan gekoöpteer word. Die komitee vergader twee maal per jaar formeel om alle kadetaangeleentheid te bespreek.

Die hoofdoel van die komitee is om die Onderwys- en Weermagowerhede te adviseer oor enige kadetaangeleenthede. Die bedryf van kadette moet dus gesien word as 'n vennootskap tussen die Onderwys en die Weermag. Elke vennootskap het bepaalde verpligtinge en moet bepaalde waarborge gee en daarvolgens hou. 'n Vereiste vir sukses is gesonde interdepartementele skakeling. Die SIK vervul hierdie rol op die bestuursvlak, terwyl die Kadetadviesrade dieselfde rol op die uitvoerdende vlak moet vervul.

Die kadetadviesrade is rade wat by elke kommandement onder voorsitterskap van die kommandementbevelvoerder funksioneer en waarop die Onderwysstreekowerhede, kommandobevelvoerders, skoolhoofde en kadetafdelingbevelvoerders sitting het. Hierdie rade vergader eenmaal per jaar om knelpunte te bespreek en om te beplan vir die lopende jaar se aktiwiteite.

\section{Doel en doelstelling van kadetopleiding}

Die Minister van Verdediging het aan die Loodskomitee opdrag gegee dat die Kadetorganisasie so geïmplementeer moet word dat dit 'n voorloper tot nasionale diensplig moet wees. Dit is dan ook die primêre doel met kadette. Die SIK was van mening dat hierdie doel te eng gestel is en het dit gewysig om te lees: 
Om kadette sinvol te oriënteer en te motiveer tov verantwoordelike burgerskap, insluitende ' $n$ liefde vir die Vaderland en 'n positiewe instelling vir nasionale diensplig.

Kommentaar. Die oriëntering verwys na die rig van die persoon dmv bepaalde kennis aan hom oor te dra, terwyl die motivering 'n gesindheidsbeïnvloeding is.

\section{Doelstellings}

Die aanwending van die volgende meganismes verseker dat hierdie doelstellings bereik word:

'n Sinvolle en uitvoerbare kadetprogram.

Behoorlike opleiding van kadetoffisiere.

Die affiliasie van kadetafdelings by Burgermagen Kommando-eenhede wat 'n soort voogdyskap oor die afdelings uitoefen en hulle behulpsaam is met opleiding en uitrusting.

Avontuuropleiding, kampe en bivakke waar seuns in ' $n$ militêre milieu opgelei word.

Uitgesoekte seuns doen verdere opleidingskursusse by Kommandemente of Groephoofkwartiere wat hulle ook direk in 'n militêre atmosfeer plaas.

Senior seuns word toegelaat om by kommandoeenhede te affilieer en neem dan deel aan skiet en ander opleiding.

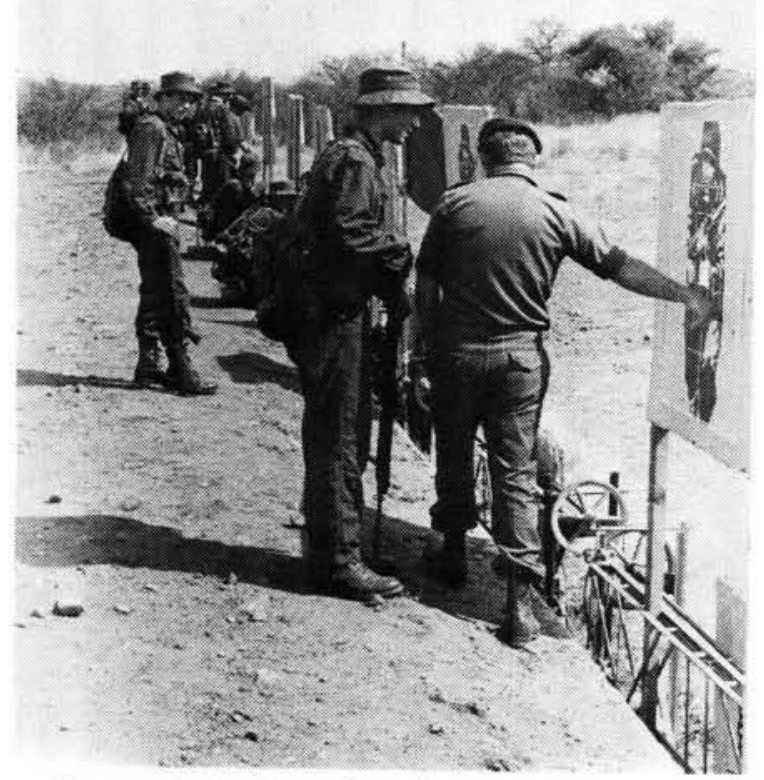

Weermaginstrukteurs leer die seuns akkuraat skiet

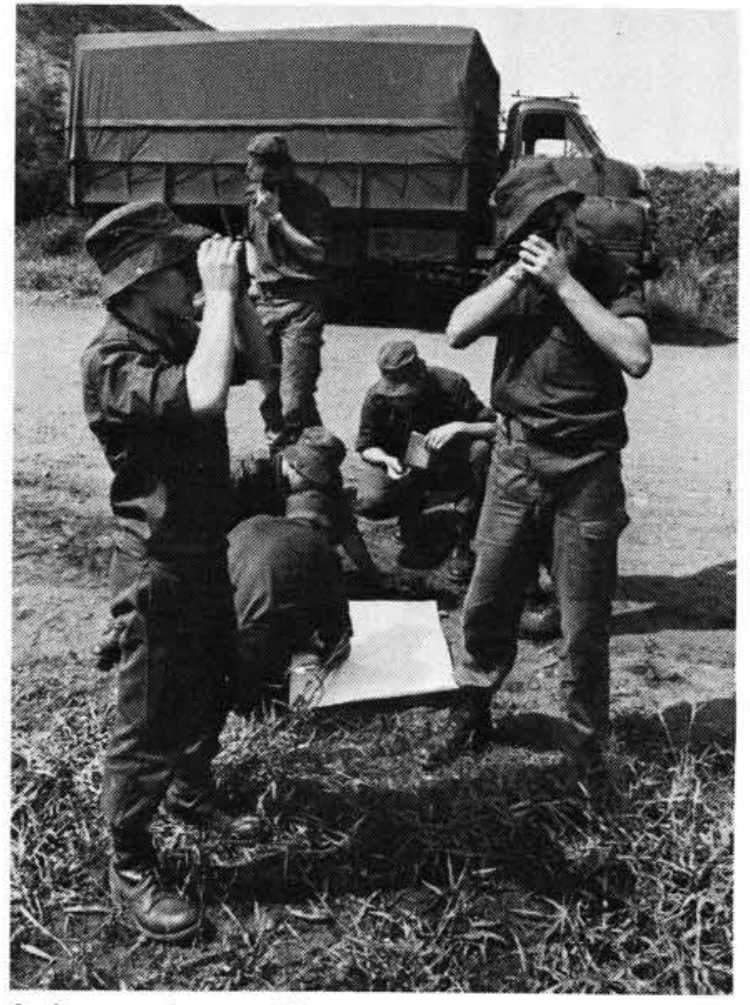

As 'n mens jou posisie moet vasstel is dit noodsaaklik om te weet hoedat kompaspeilings geneem word

Die volgende sekondêre doelstellings word ook nagestreef:

Om sodanige kennis aan die kadet oor te dra dat hy bevredigende militêre vaardighede, binne die perke van sy vermoë, sal ontwikkel sodat hy tydens diensplig doeltreffend sal aanpas.

Om by die kadet ' $n$ persoonlike trots en liefde te laat gedy tov sy kadetafdeling, die SA Weermag en sy land.

Om die kadet die geleentheid te gee om medeverantwoordelik te voel vir die veiligheid van sy eie gemeenskap.

Om die kadet te bewapen met kennis omtrent die aard en omvang van die bedreiging teen die RSA en hoe dit teengestaan word.

Om die kadet die geleentheid te gee om wapens en militêre uitrusting met veiligheid en verantwoordelikheid te leer, hanteer en te versorg. Om die kadet die waarde van groepoptredes (Esprit de Corps) en dissipline, veral in die militêre milieu, in te skerp.

Om die kadet se leierskap-potensiaal en 'n wil om persoonlik betrokke te raak, te ontwikkel.

\section{Die filosofie en program vir kadetopleiding}

Die onderwys en die Weermag het 'n besondere siening tov die filosofie van kadetopleiding. Hierdie filosofie is in breë trekke die volgende: 
Die Kabinet se besluit om ' $n$ kadetprogram in sekondêre skole in te stel, maak dit vir die Onderwys moontlik om seuns beter vir die lewenswerklikhede in die wêreld en in die RSA voor te berei, omdat hull nou ' $\mathrm{n}$ kanaal/platform het waarvandaan hulle dit kan doen. Onderwysvakke verleen hulle nie maklik daarvoor nie.

Om sy verantwoordelikheid teenoor sy leefwêreld te kan nakom is dit nodig dat elke seun lief word vir die RSA, trots raak op die land se Weermag en bewus gemaak word van sy verantwoordelikheid teenoor sy medemens en die land waarin hy woon.

Kadette is uitnemend geskik daarvoor om by seuns 'n gevoel van egte trots vir hulle eie aan te wakker. Deur hulle avontuurlustigheid, lewenskragtige jeugdigheid en natuurlike waaghouding is seuns nie alleen bereid om saakmakend by elke stryd in en om hulle leefwêreld betrokke te raak nie, maar is hulle besonder opleibaar in die aanleer van spesifieke vaardighede en vatbaar vir die besef dat fisiese en geestelike weerbaarheid elke individu se eie verantwoordelikheid is.

Waar kadette deur twee vennootdepartemente naamlik Onderwys en die SAW bedryf word, is daar kundighede uit die militêre milieu sowel as uit die opvoedkundige oogpunt beskikbaar. Dit verseker dat die kadetopleidingsprogram suksesvol aangebied kan word en dat die moreel en geesteskrag van Suid-Afrikaners verhoog word.
Beginnende by die bevordering van ' $n$ trots op homself (sy flinke optrede en netheid in uniform) sy kadetafdeling en sy skool word die kadet gelei tot ' $n$ trots op sy land en die SAW.

Die kadetprogram bevorder noodsaaklike psigomotoriese vaardigheid en trots, maar bevorder veral ook dissipline en die besef dat daar tye is wanneer bevele gehoorsaam word sonder om die opdrag te evalueer of te bevraagteken.

Die komponente van die kadetprogram is sodanig gekies dat noodsaaklike opvoedingsgeleenthede geskep word en 'n samehorigheidsgevoel bevorder word. Daar word egter besonder klem gelê op diè aanleer van die soort kennis, die inoefen van diè tipe vaardighede en die bevordering van diè lewenshouding wat die seun se aanpassing tydens militêre diensplig sal vergemaklik.

\section{Die kadetprogram}

Die kadetprogram (sillabus) is sodanig saamgestel dat sekere komponente (vakke) gedurende die twee periodes (ongeveer 1 uur) wat aaneenlopend tot die skooldag is, aangebied kan word, terwyl die praktiese vakke gedurende kampe en bivakke in 'n militêre milieu aangebied moet word. Dit is daarom dan ook belangrik dat elke seun gedurende sy hoërskooljare die geleentheid moet kry om 'n kamp by te woon. Die klem van kadetopleiding val op motivering, skiet, dril en deelname aan kompetisies.

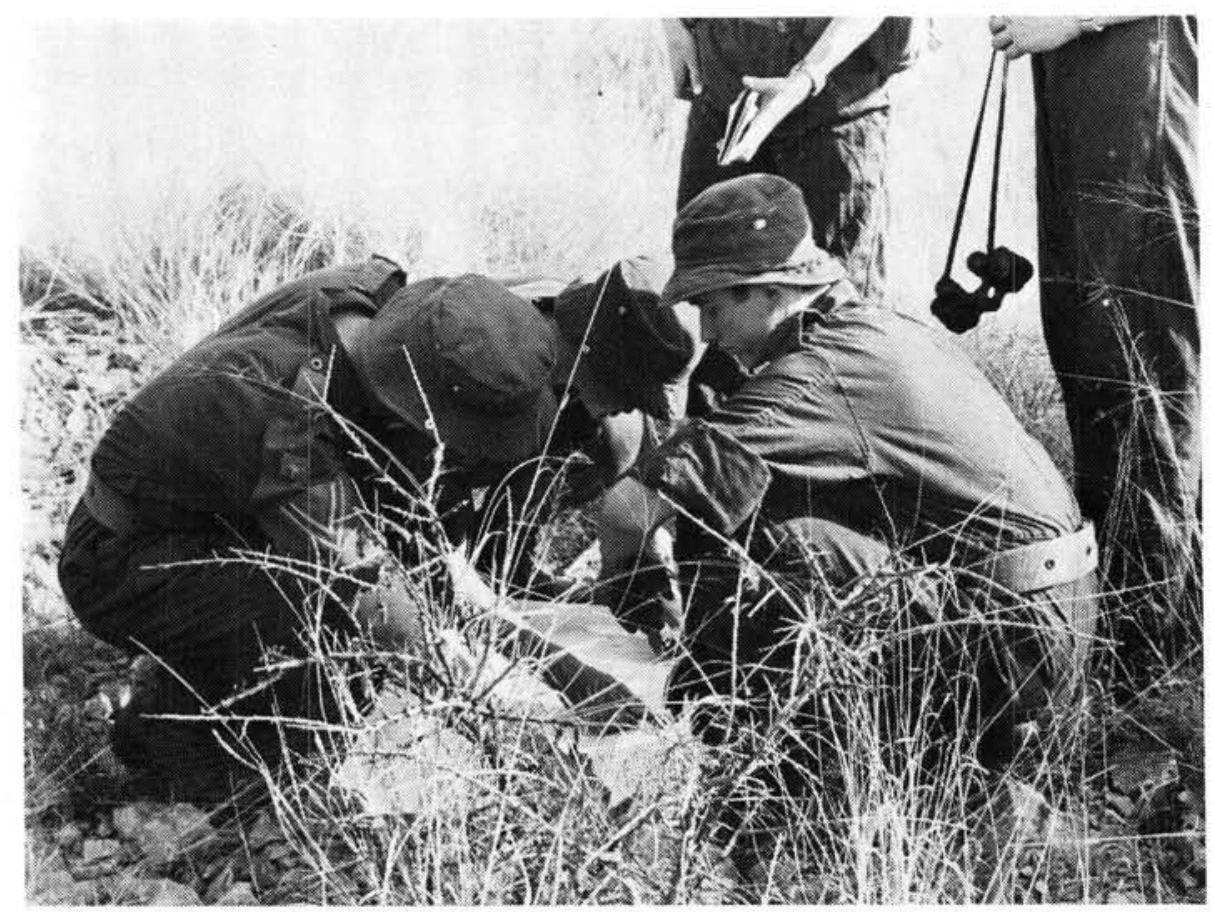

Met of sonder 'n kompas - 'n kaart bly 'n handige instrument, veral as mens hom verstaan 
Die hoofkomponente van die kadetprogram is: Dril, Skietkuns, Kaartlees en navigasie, Radiospraakprosedures, Salueer en eerbewys, Veldkuns, Militêre dissipline en leierskap, Organisasies in die SA Weermag, Interne dienste in ' $n$ eenheid, Inligting en sekerheid, Beskerming van huis en haard wat skool- en koshuisbeskerming insluit en laastens moet kadette kennis neem van die bedreiging teen die land.

Elke hoofkomponent is weer onderverdeel in subkomponente wat die detail van die leerplan voltooi. Vir elke komponent is daar 'n bepaalde tydstoekenning per standerd. Die program is ook sodanig saamgestel dat dit gedifferensieerd toegepas kan word. Elke skool pas die program aan volgens eie unieke omstandighede (byvoorbeeld beskikbare offisiere, fasiliteite, aantal kadette en tipe skool en die vermoë van die kind) die programinhoud is verder uitgewerk in komponent- en subkomponentdoelwitte. Daar word dus gepraat van die doelwitprogram vir kadetopleiding. Hierdie doelwitleerplanne is per vak per standerd uitgewerk om aan te pas by die ontwikkeling van die kind.

Laastens word dit beklemtoon dat die kadetprogram 'n gesamentlike produk van die Weermag en die Onderwys is met die klem op die opvoedkundige verantwoordbaarheid daarvan.

\section{Die kadetoffisiere}

Daar is vrywillige sowel as dienspligtige onderwysoffisiere wat tans by kadette betrokke is. Die kadetoffisier is in die eerste plek ' $n$ kommandoof burgermagoffisier. Hulle is dus goed opgelei. Sedert 1977 word alle dienspligonderwysers in een bataljon by die Infanterieskool saamgetrek vir leiersopleiding wat ' $n$ jaar duur. Dit sluit drie maande operasionele diens as 'n groep (eenheid) in. Gedurende hulle tweede jaar doen hulle diens by dienspligeenhede as pelotonbevelvoerders en bring weer lang periodes in die operasionele gebied deur, waar baie van hulle aksie sien. Daar bestaan dus geen twyfel oor hierdie manne se vermoë om die beeld van soldaatwees by die jong seun tuis te bring nie en om uitvoering aan die program te gee nie.

\section{Kompetisies}

Alhoewel die hoofklem nie op kompetisies val nie, vorm dit die hoogtepunt van die kadetbedrywighede.
Behalwe vir kompetisies wat op die lokale vlak binne die Kommandemente ingestel is, is die algemene voorgeskrewe kompetisies die volgende:

Die SA Tussenafdeling Dril-, Skiet-en Orkeskompetisie wat binne elke kommandement gehou word. Al die kadetafdelings binne ' $n$ kommandementsgebied neem hieraan deel. Uitdunne vind op Streeksvlak plaas en die finaliste kompeteer op 'n gegewe dag teen mekaar.

Die SA Tussen-afdelingskietkompetisie is ' $n$ posliga wat deur al die kadetafdelings in die land in hulle eie tyd volgens voorgeskrewe tabelle geskiet word. Die resultate word finaal deur Leërhoofkwartier gekontroleer, wat dan die wenners aanwys en die trofees vir die verskillende fasette daarvan uitgegee.

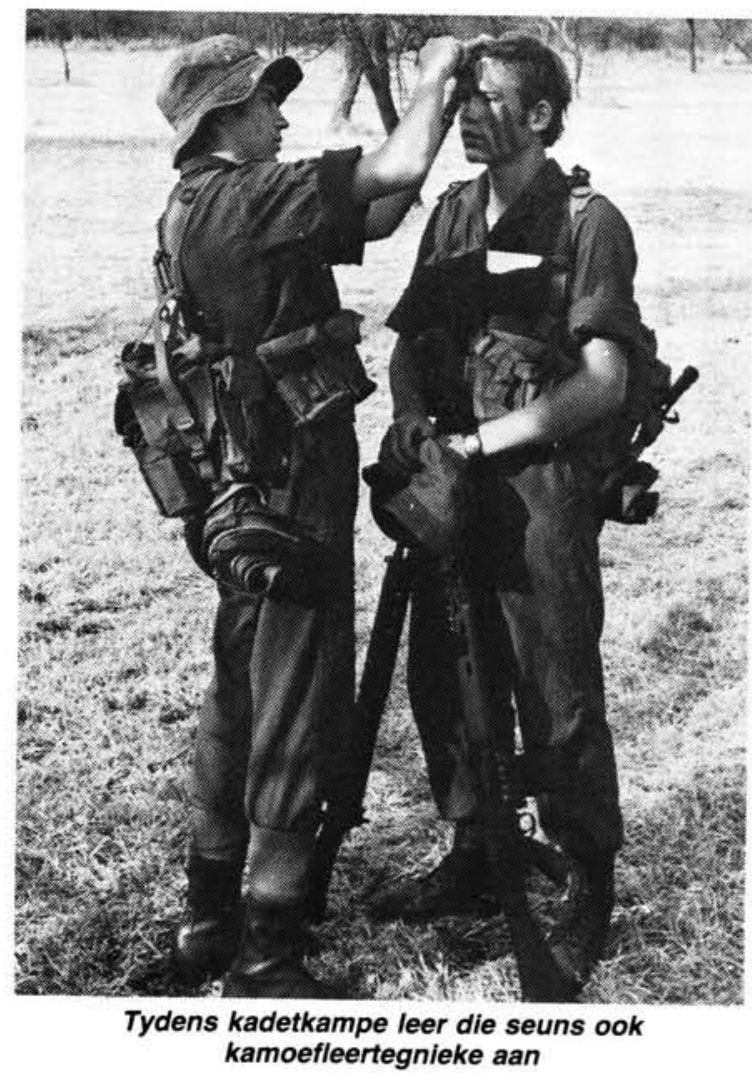

Die kulmunasie van alle skietaktiwiteite is die nasionale kadetbisley wat jaarliks plaasvind. Skuts van oor die hele land ding hier mee vir verskillende trofees. Daar is span- en individuele kompetisies vir juniors en vir seniors. Waardevolle trofees en gesogte medaljons kan hier gewen word. Dit is die enigste kompetisie wat op nasionale vlak gehou word.

Daar is ook nog 'n baie gesogte skiettrofee wat 
jaarliks aan die kommandement toegeken word wat aan die hand van spesifieke bepalinge die meeste gedoen het om skiet in sy gebied te bevorder. Hierdie trofee, die Genl-maj W.A. Lombard trofees is verlede jaar ingestel en is gewen deur Kommandement Suid-Kaap.

\section{Statistiek}

Die stand van kadette in die land tov personeel en uitrusting sien tans soos volg daaruit:

\begin{tabular}{|l|l|l|l|l|l|}
\hline $\begin{array}{l}\text { Personeel/ } \\
\text { Uitrusting }\end{array}$ & TOD & KOD & $\begin{array}{c}\text { Na- } \\
\text { tal }\end{array}$ & OVSOD & $\begin{array}{l}\text { To- } \\
\text { taal }\end{array}$ \\
\hline $\begin{array}{l}\text { Kadetafdelings } \\
\text { Kadette } \\
\text { Offisiere }\end{array}$ & $\begin{array}{l}262 \\
105,136\end{array}$ & $\begin{array}{l}237 \\
1201\end{array}$ & 69 & 90 & 658 \\
& & 934 & 25,754 & 15,349 & 193,254 \\
Skietbane & 203 & 174 & 53 & 89 & 2942 \\
Orkeste & 207 & 199 & 43 & 65 & 511 \\
\hline
\end{tabular}

Daar is tans slegs ongeveer 20 privaatskole en tien staatskole wat nog nie kadetafdelings het nie.

\section{Vergelyking van die stelsel voor 1974 en die huidige stelsel}

Die ontstaan van kadette in ons land was 'n direkte gevolg om die bedreiging, wat daar van vyandiggesinde inboorlingvolke gekom het, af te weer. In die moderne militêre taal sal ons sê hulle taak was om huis-en haard te beskerm. Kadette het dus 'n militêre oorsprong, maar was terselfdertyd van die begin af opvoedkundig gefundeer aangesien dit ' $n$ aktiwiteit was wat by die skool beoefen is en waarby onderwysers hoofsaaklik betrokke was.

Dit is vandag nog 'n militêre georiënteerde opvoedkundige- gefundeerde organisasie waarmee ons egter iets anders wil bereik as die rede waarvoor dit aanvanklik ingestel is.

Die eerste wetgewing oor kadette (1913) en die van die huidige wetgewing (Wet 44 van 1957) verskil weinig. Kadette is verpligtend vir alle staatskole volgens albei wetsbepalings.

Die doel van kadette soos geformuleer in 1913 en die doel soos bepaal in 1974 is ook feitlik dieselfde. Die seun moet voorberei word vir sy latere verpligting as landsburger. Dit gaan egter in hoofsaak oor die kweek van 'n positiewe gesindheid.

Die inhoud van die opleidingsprogram het ook nie drasties verander nie. In die huidige stelsel is die program verfyn, georden, en gedifferensiëer om by die opvoedkundige eise aan te pas en is elke subkomponent van die program in duidelike doelwitte geformuleer.

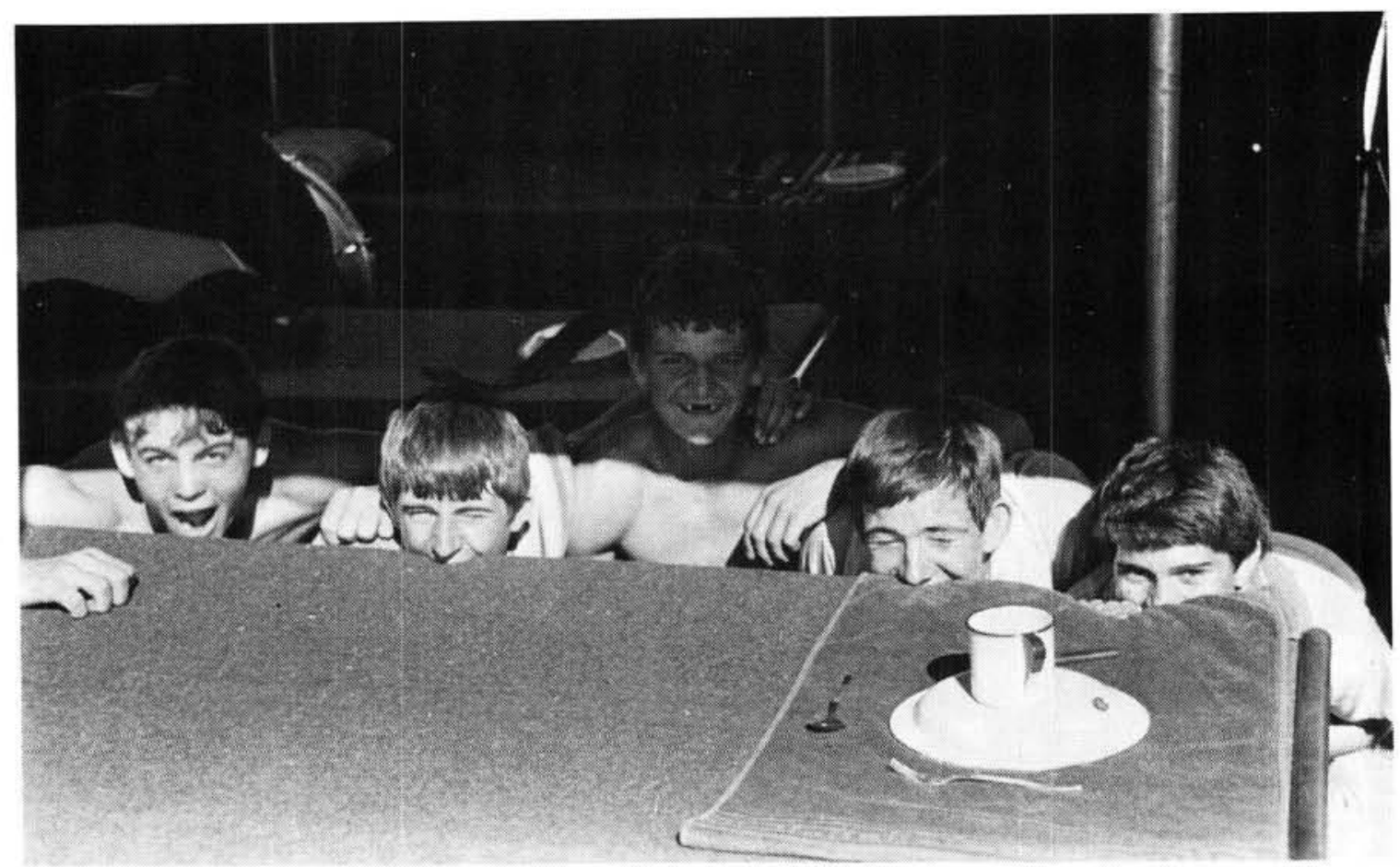

“Kyk, Ma, geen tande...". Tussen die opleiding is daar ook af en toe tyd vir 'n grappie 
Tov die kompetisies het daar ook rasionalisering plaasgevind om by veranderde omstandighede en behoeftes aan te pas en om dit sinvol te mak. Die opleiding van die onderwyser het drasties verander. Die kadetoffisiere, en by uitstek diegene wat gedurende die afgelope ongeveer 15 jaar by kadetafdelings betrokke geraak het, is volwaardige Weermagoffisiere wat militêr sodanig opgelei is dat dit op sigself al ' $n$ sterk motiveringsfaktor vir die kadet is.

Die feit dat die meeste van hierdie jong manne reeds ondergeskiktes in operasies gelei het en aan die skerpkant aangewend was, maak hulle aanvaarding by die seuns sterker. Die grootste verskil in die ou en die nuwe stelsel lê waarskynlik daarin dat daar skakelkanale op alle vlakke geskep is en dat dit behoorlik funksioneer. Die twee departemente werk nou saam as volwaardige vennote na 'n gemeenskaplike doelwitbereiking. Die Stelsel is op nasionale vlak eenvormig en word op die hoogste vlak gekoördineer. En tog word daar voldoende ruimte aan elke onderwysdepartement gelaat om binne die beginsels van eenvormigheid en gekoördineerdheid kadette in hulle gebied, in samewerking met die betrokke Kommandement volgens eie interne behoeftes en omstandighede te bedryf.

\section{Slot}

Die twee hoof vereistes vir die effektiewe bedryf van kadette is eerstens ' $n$ gesonde interdepartementele skakeling en samewerking en die regte begrip vir elkeen se verantwoordelikheidsveld in die vennootskap. Kadette is primêr ' $n$ onderwysverantwoordelikheid, terwyl die Weermag ondersteunend optree. In die tweede plek berus die sukses van die stelsel by die onderwyseroffisier. Sy kennis, sy selfmotivering en sy beskouing tov Vaderlandsliefde, diensplig, ens bepaal of hy die seun kan motiveer, en of hy dit sodanig gaan doen dat die doel en doelstellings verwesentlik gaan word.

"Kol M.J. Viljoen is SSO Kadette en Burgerlike Beskerming, Leërhoofkwartier.

\author{
Bibliografie \\ 1. Queen's College Centenary Brochure 1877-1977. \\ 2. Commando. \\ 3. Paratus. \\ 4. Military History Journal. \\ 5. Defence Act No 44 of 1957 \\ 6. Union Gazette No 378 (28 February 1913). \\ 7. Government Gazette No 1448 (25 August 1923). \\ 8. Government Gazette No 591 (4 May 1934). \\ 9. Loodsverslag oor kadette, 1974.
}

